\title{
EVALUATION OF OCCUPATION HOT EXPOSURE IN INDUSTRIAL WORKPLACES IN A SUBTROPICAL COUNTRY
}

\author{
YU-CHIAO YANG ${ }^{1,2}$, MING-CHI WEI ${ }^{3}$, and SHOW-JEN HONG ${ }^{1}$ \\ ${ }^{1}$ Kaohsiung Medical University, Kaohsiung, Taiwan \\ Department and Graduate Institute of Pharmacology \\ ${ }^{2}$ Kaohsiung Medical University Hospital, Kaohsiung, Taiwan \\ Department Medical Research \\ ${ }^{3}$ Chia Nan University of Pharmacy and Science, Tainan, Taiwan \\ College of Sustainable Environment, Department of Applied Geoinformatics
}

\begin{abstract}
Objectives: The objective of this study has been to evaluate the occupational heat exposure of 12 workers at 5 plants in a subtropical country. Material and Methods: The heat stresses and strain on workers in 5 plants were assessed by the International Organization for Standardization (ISO) 7243 index (wet bulb globe temperature - WBGT) and the ISO 7933 index (maximum allowable exposure time $-\mathrm{D}_{\mathrm{lim}}$ ). Results: Results indicated that $42 \%$ of the subjects (5 workers) surpassed the WBGT limits. According to the $\mathrm{D}_{\text {lim }}, 42 \%$ of the subjects could not continue working in the hot environments. The relationships between the various heat stress indices and the WBGT index were also correlated. However, further studies from different heat environments and more subjects should be performed. Conclusions: The sensitive dependence of skin temperature on meteorological and physiological indices for each subject was clearly observed. Obviously, the heart rate response to metabolic rate was much greater than that caused by environmental heat alone. The exponential relationship between workers' duration-limited exposure time, predicted by various estimated criteria, and WBGT were also found. Int J Occup Med Environ Health 2017;30(3):379-395
\end{abstract}

Key words:

Skin temperature, Heart rate, Heat stress, Wet bulb globe temperature, Maximum allowable exposure time, Metabolic rate

\section{INTRODUCTION}

Heat stress is prevalent in some industrial workplaces, such as the metal, glass, mining, ceramic, construction industries as well as engine or boiler rooms; workers are frequently exposed to heat stresses above conventional limits. Workers are often exposed to severe environmental heat stresses, which may deteriorate work efficiency and productivity and may even be life threatening. The International Organization for Standardization (ISO) 7243 index (wet bulb globe temperature - WBGT) [1,2] and

Funding: the article was financially supported by the National Science Council of Taiwan, Kaohsiung Medical University (Office of Research and Development, Center for Researchs and Development) (KMU-M106034 \& M104020), grant manager: Yu-Chiao Yang, Ph.D., and Chuang Song Zong Pharmaceutical Co., Ltd. (Kaohsiung, Taiwan) (S 102035 \& S 102036).

Received: August 4, 2015. Accepted: March 1, 2016.

Corresponding author: M.-C. Wei, Chia Nan University of Pharmacy and Science, College of Sustainable Environment, Department of Applied Geoinformatics, No. 60, sec. 1, Erren Rd., Rende District, Tainan 71710, Taiwan (e-mail: s120702@mail.cnu.edu.tw). 
the ISO 7933 index (maximum allowable exposure time - $\left.\mathrm{D}_{\text {lim }}\right)[3,4]$ are recommended by the International Organization for Standardization (ISO) as the international standard for assessing heat load. The aim of both standards is to regulate chronic exposure to heat stresses, and the World Health Organization (WHO) [5] has adopted a core body temperature of $38^{\circ} \mathrm{C}$ as its upper limit. The WBGT index is by far the most commonly used heat stress index throughout the world (e.g., it is used in Australia, China, India, Japan, the United Kingdom (UK), the United States of America (USA), and the European Union). It was developed by Yaglou and Minard [6] to reduce the incidence of heat illness during military training, and it gained popularity mainly due to its relative simplicity and convenience of use. This index has also been adopted by other organizations to prevent heat injuries [7-9]. Despite the almost ubiquitous application of the WBGT index, evidence suggests that the index has several significant limitations. The estimation of metabolic rate, variations in skin temperature or skin dampness, the effects of air velocity, and the effects of clothing all limit the efficacy of the index. Nevertheless, several studies have used the WBGT index as a safety index for workers across various vocations [10-12].

If the WBGT values of the hot environment exceed the WBGT reference values, or if a more detailed analysis is required, then the ISO 7933 standard [3,4] proposes an analytical method of evaluating heat stress. The ISO 7933 standard [3] is derived from the Belding and Hatch heat stress indexes (HSI) criteria [13], which represents the determination and interpretation of heat stress using calculation of the required sweat rate $\left(\mathrm{SW}_{\text {req }}\right)$ and is derived from the thermal equilibrium of the human body through a balance between metabolic heat production and heat dissipation from the body. The ISO 7933 standard [3] determines the required sweat rate and is considered more detailed risk than the WBGT index, and therefore, it is a better method for predicting uncompensable heat-stress.
Comparison different heat-stress indices has shown that the ISO 7933 standard [3] affords the best prediction of strain caused by muscular work and heat whether strain is measured by sweat rate, heart rate or core body temperature [14]. Some data supports the use of a required sweat rate as a trustworthy indicator of response to heat stress, while other data supports a conflicting conclusion. Kampmann and Piekarski [15] delineated the considerable discrepancies between the actual sweat rate and the sweat rate predicted by the method as well as between the actual and predicted core body temperature. Work by Kähkönen [16] showed similar problems when testing the method across several industries. Furthermore, several studies have shown that the ISO 7933 standard [3] is not valid in conditions where protective clothing, high levels of radiation, high humidity, high air velocity or saturated clothing are involved [17].

Mehnert et al. [18] demonstrated that the prediction of mean skin temperature used for the ISO 7933 standard [3] purposes was not valid in places with high levels of radiation or humidity. For the best prediction of strain, the predicted heat strain (PHS) model was developed to predict the required sweat rate as well as rectal temperatures $[19,20]$, and the values predicted by this model are comparable to the ISO 7933 standard [3,4]. The PHS has been entirely replaced by the revised reversion of the ISO 7933 standard [3]. The 2004 revised standard [4] includes amendments to the algorithms (PHS index) that predict changes in sweat rate and internal body temperature in response to heat and amendments to the maximum allowable exposure times $\left(\mathrm{D}_{\lim }\right)$. The $\mathrm{D}_{\lim }$ is reached when either the cumulated water loss or the rectal temperatures reaches the corresponding maximum values. Comparisons between the cumulated water loss and the rectal temperatures have found that the cumulated water loss is a useful indicator for the instruction of workers in extremely hot environments and for ensuring their health and safety. 
To assess the maximum allowable exposure time, the maximum water loss is set at $7.5 \%$ of the body mass $\left(\mathrm{D}_{\max 50}\right.$, average or median subject) and $5 \%$ of the body mass $\left(\mathrm{D}_{\text {max } 95}\right.$, most susceptible subject). Thus, the $\mathrm{D}_{\lim }$ may be calculated for an average subject on the basis of a maximum water loss of $7.5 \%$ of the body mass and on the basis of $5 \%$ of the body mass in order to protect $95 \%$ of the working population. However, compared to the previous required sweat rate index (ISO 7933 1989) [3], the 2004 revised ISO 7933 standard [4], there are also such similar limitations in conditions where protective clothing, high levels of radiation and high humidity are involved [21,22]. Moreover, many different models, such as the environmental stress index (ESI) [23], discomfort index (DI) [24], modified discomfort index (MDI) [25], effective temperature (ET) [26], corrected effective temperature (CET) [27], equivalent temperature $\left(\mathrm{T}_{\mathrm{eq}}\right)$ [28] and operative temperature $\left(\mathrm{T}_{0}\right)$ (ISO 7730) [29] have been proposed as alternatives to rational methods of heat-stress evaluation. The different methods for evaluating heat stress all have advantages and disadvantages. However, the differences between the various heat-stress indices and the WBGT are rare in the literature. In addition, heat stress is generally related to meteorological parameters and physiological variables.

During exposure to hot environments, various physiological responses have been used as criteria for assessing the physiological heat stress, e.g., required sweat rate $\left(\mathrm{SW}_{\text {req }}\right)[3,4]$, rectal temperature $[5,30,31]$, oral temperature [31-33], skin temperature [18,32,33] and heart rate [33]. To the best of the author's knowledge, there has been little scrutiny of the relationship between meteorological parameters and physiological variables.

To address this gap, this study correlates the various evaluation criteria with the WBGT index in 4 heavy-oil power plants and 1 coal-fueled power plant. The correlations between the various heat-stress indices and the physiological responses, such as sweat rate, skin temperature, metabolic rate, oral temperature and heart rate, are also discussed.

\section{MATERIAL AND METHODS}

\section{Test locations and subject descriptions}

Four heavy-oil power plants and 1 coal-fueled power plant were surveyed (Table 1). All 4 heavy-oil power facilities had similar heat sources but varied in the size of the boiler and the type of production (designated as plants A, B, C, and D). Plant E (paper plant) was a coal-fueled power plant, which had the high radiant heat generated from the boiler. All 5 plants were in the city of Tainan (southern part of Taiwan), and this region was extremely hot during the summer months. The dry air temperatures ranged frequently $30-40^{\circ} \mathrm{C}$ in July and August.

Monitoring of both area and personal heat stress was performed during the summer months to try to establish the hottest working conditions. Prior to beginning the experimental trials, the supervisors and/or employees of each plant were interviewed to identify those employees at the highest risk for heat strain. Based on these interviews, test locations were selected around the mobility zones of workers and their respective refreshment rooms as well as outside the buildings in the shade. A detailed description of each test location is also provided in the Table 1. All 12 workers in this study were men ranging 27-51 years old ( $34.5 \pm 10.6$ years) who had been employed in these facilities for at least 6 months. Therefore, they were all considered experienced and acclimatized workers. Their average height \pm standard deviation and weight \pm standard deviation were $168.4 \pm 5.9 \mathrm{~cm}$ and $68.6 \pm 7.3 \mathrm{~kg}$, respectively.

\section{Meteorological measurements}

This research was done in July and the selected plants were in the city of Tainan, Taiwan. Environmental parameters including dry-bulb temperature $\left(\mathrm{T}_{\mathrm{a}}\left[{ }^{\circ} \mathrm{C}\right]\right)$, natural wet-bulb temperature $\left(\mathrm{T}_{\mathrm{nw}}\left[{ }^{\circ} \mathrm{C}\right]\right)$, wet bulb temperature $\left(\mathrm{T}_{\mathrm{w}}\left[{ }^{\circ} \mathrm{C}\right]\right)$, globe temperature $\left(\mathrm{T}_{\mathrm{g}}\left[{ }^{\circ} \mathrm{C}\right]\right)$, and air velocity $\left(\mathrm{V}_{\mathrm{a}}[\mathrm{m} / \mathrm{s}]\right)$, were measured. All instruments compliant with the ISO 7726 [34] and ISO 7243 [2] 
Table 1. Test locations in the study evaluating the occupational heat exposure of 12 workers at 5 plants in a subtropical country

\begin{tabular}{|c|c|}
\hline Location & Description \\
\hline Plant A & boiler room of textile plant, heat source: $15 \mathrm{t} / \mathrm{h}$ heavy oil-boiler, 1 worker \\
\hline 1 & approximately $2 \mathrm{~m}$ from the boiler front \\
\hline 2 & passageway \\
\hline 3 & rest room \\
\hline 4 & outside of building in shade \\
\hline Plant B & dye vat department of textile plant, heat source: $15 \mathrm{t} / \mathrm{h}$ heavy oil-boiler, 4 workers \\
\hline 1 & dye vat stove, side \\
\hline 2 & passageway \\
\hline 3 & dye vat stove, side \\
\hline 4 & furnace, side \\
\hline 5 & boiler, side \\
\hline 6 & outside of building in shade \\
\hline Plant C & boiler room of forage plant, heat source: $9.6 \mathrm{t} / \mathrm{h}$ heavy oil-boiler, 1 worker \\
\hline 1 & boiler, side \\
\hline 2 & boiler, side \\
\hline 3 & approximately $2 \mathrm{~m}$ from the boiler front \\
\hline 4 & rest room \\
\hline 5 & outside of building in shade \\
\hline Plant D & tinplate division department of tinplate plant, heat source: $20 \mathrm{t} / \mathrm{h}$ heavy oil-boiler, 5 workers \\
\hline 1 & passageway \\
\hline 2 & toaster, side \\
\hline 3 & toaster, side \\
\hline 4 & package area \\
\hline 5 & rest room \\
\hline 6 & boiler, side \\
\hline 7 & outside of the building in the shade \\
\hline Plant E & boiler room of paper (pulp) plant, heat source: $120 \mathrm{t} / \mathrm{h}$ coal-boiler, 1 worker \\
\hline 1 & boiler, side \\
\hline 2 & boiler, front \\
\hline 3 & boiler, side \\
\hline 4 & boiler, rear \\
\hline 5 & boiler, feed-side \\
\hline 6 & rest room \\
\hline 7 & outside of building in shade \\
\hline
\end{tabular}

requirements. Experimental instrumentation, including the mercury-in-glass thermometers, Assmann psychrometer (KP-25, Komatsu Factory Co., Ltd., Japan) and a hot wire anemometer (model KA22, Kanomax, Japan), were calibrated prior to each trial. All measurements were taken at a height of $110 \mathrm{~cm}$ (chest height 
of the worker) to represent heat exposure to the trunk, and the measurements were recorded every $15 \mathrm{~min}$ between 9 a.m. and 3 p.m. Instruments were left at each location for $20 \mathrm{~min}$ to reach equilibrium.

\section{Physiological measurements}

At each of the surveyed plants, 1 observer followed 1 worker for the entire work shift (time-motion study). The operation characteristics, work time, rest time, clothing and volume of water intake were monitored during the work shift. During the summer, workers wore underpants, light-weight trousers, short-sleeve shirts or T-shirts, socks and shoes assuming an approximate clothing insulation $\left(\mathrm{I}_{\mathrm{cl}}\right)$ of $0.6 \mathrm{clo}$ (where 1 clo $=0.155 \mathrm{~m}^{2}-\mathrm{C} / \mathrm{W}$ ). Several times during each work shift, the observer would survey the post-exercise recovery heart rate of the worker. Whenever possible, these measurements were made at times when the worker would normally stop to rest. The heart rate (HR) of each worker was also counted for 1 min after specific tasks $[32,35,36]$. Heart rates were taken at least twice to confirm the values. Workers were seated for these measurements.

\section{Calculations}

The WBGT index and the variables of the ISO 7933 standard were calculated according to the ISO 7243 (2003) [2] and ISO 7933 (2004) [4], respectively. Mean radiant temperature $\left(\mathrm{T}_{\mathrm{r}}\right)$ was calculated according to the ISO 7726 [34], using the following equation:

$$
\mathrm{T}_{\mathrm{r}}=\left[\left(\mathrm{T}_{\mathrm{g}}+273\right)^{4}+2.5 \times 10^{8} \times \mathrm{V}_{\mathrm{a}}^{0.6}\left(\mathrm{~T}_{\mathrm{g}}-\mathrm{T}_{\mathrm{a}}\right)\right]^{0.25}-273
$$

where:

$\mathrm{T}_{\mathrm{r}}$ - mean radiant temperature,

$\mathrm{T}_{\mathrm{g}}$ - globe temperature,

$\mathrm{V}_{\mathrm{a}}$ - air velocity,

$\mathrm{T}_{\mathrm{a}}$ - dry-bulb temperature.

All temperatures are in ${ }^{\circ} \mathrm{C}$ and $\mathrm{V}_{\mathrm{a}}$ is in $\mathrm{m} / \mathrm{s}$.
The Belding and Hatch heat stress index (HSI) was calculated according to the Belding and Hatch HSI criteria [13]. Effective temperature (ET) and corrected effective temperature (CET) were estimated from psychrometric charts using an Assmann psychrometer. In addition, several indices, including operative temperature $\left(\mathrm{T}_{\mathrm{o}}\right)$, equivalent temperature $\left(\mathrm{T}_{\text {eq }}\right)$, Oxford index (wet-dry index - WD), discomfort index (DI), fighter index of thermal stress (FITS), modified discomfort index (MDI), environmental stress index (ESI), wet-bulb dry temperature (WBDT), and relative humidity dry temperature (RHDT), were also estimated based on the published literature [13,23-29,37].

According to the workers' operation characteristics, work time and rest time, the time-weighted averages of heart rates were obtained to estimate the time-weighted averages (TWAs) of heat-stress indices. The time-weighted averages of the employees' metabolic rates were also compared using the metabolic rate tables available in the literature $[1,7,9,38]$. The calculated time-weighted averages (TWAs) of heat-stress indices were compared with recommended TWAs and upper limits from the published literature $[1,3,7,9]$.

\section{Statistical analysis}

Environmental conditions during the test days were averaged for $5 \mathrm{~h}$ each working day ( 9 a.m. -3 p.m.), and data is presented in this study as means \pm standard deviations $(\mathrm{M} \pm \mathrm{SD})$. Data analysis included constructing linear models which were used for defining the correlation between the WBGT and various evaluation criteria. Correlations and regressions between 3 different physiological variables $\left(\mathrm{T}_{\mathrm{sk}}, \mathrm{HR}\right.$, and $\left.\mathrm{SW}_{\text {req }}\right)$ and various indices were determined for all data points. The analysis of variance (ANOVA) was carried out using Tukey's method with a significance level of $p<0.05$ using 2010 Microsoft Office Excel (Microsoft Co., USA) and Origin software version 6.1 (Origin Lab Co., USA). 


\section{RESULTS}

\section{The evaluation of meteorological parameters}

From the $\mathrm{T}_{\mathrm{a}}$ and $\mathrm{T}_{\mathrm{w}}$ data, the relative humidity, and ambient water vapor pressure $\left(\mathrm{P}_{\mathrm{a}}\right)$ were determined with a psychrometric chart. Ranges and means \pm standard deviations for each variable at each measurement site are given in the Table 2. All averages correspond to the average of measurements taken from 9 a.m. to 3 p.m. These ambient temperatures and relative humidity are readily available and thus tempting metrics for heat stress assessment [39]. The $T_{a}, T_{n w}, T_{w}$, and $T_{g}$ in the coal-fueled power plant (plant $\mathrm{E}$ ) were higher than the temperatures in the heavyoil power plants (plants $\mathrm{A}, \mathrm{B}, \mathrm{C}$ and $\mathrm{D}$ ). The $\mathrm{T}_{\mathrm{g}}$ of plant $\mathrm{E}$ ranged $40.45-50.58^{\circ} \mathrm{C}$ due to the higher radiant energy load. Notably, the temperature outside the building in the shade ranged $29.55-33.99^{\circ} \mathrm{C}$ for $\mathrm{T}, 24.19-27.21^{\circ} \mathrm{C}$ for $\mathrm{T}_{n w}, 25.14-28.12^{\circ} \mathrm{C}$ for $\mathrm{T}_{\mathrm{w}}$, and $33.77-36.10^{\circ} \mathrm{C}$ for $\mathrm{T}_{\mathrm{g}}$ during this study. The results reveal that the weather in subtropical climates is relatively hot and humid $(68.36 \pm 2.54 \%)$ during the summer months. Additionally, as it may be seen from the Table 2, it may be speculated that the rest areas were air-conditioned and had significantly lower temperatures than work areas.

\section{Relationships between the WBGT index and various heat-stress indices}

Using the data in the Table 2 and the mean radiant temperature $\left(\mathrm{T}_{\mathrm{r}}\right)$ (equation (1)), the values of various heatstress indices were determined for each of the work positions studied. To appraise the relationships between the various heat-stress indices and the WBGT index, this study correlated the 11 indices with the WBGT index, and these results are tabulated in the Table 3. All statistical contrasts were accepted at the $\mathrm{p}<0.05$ level of significance. All statistical analyses were performed using an Excel spreadsheet and an Origin version 6.1.

This table provides the numbers of observations $(\mathrm{N})$, corresponding regression equations, and correlation

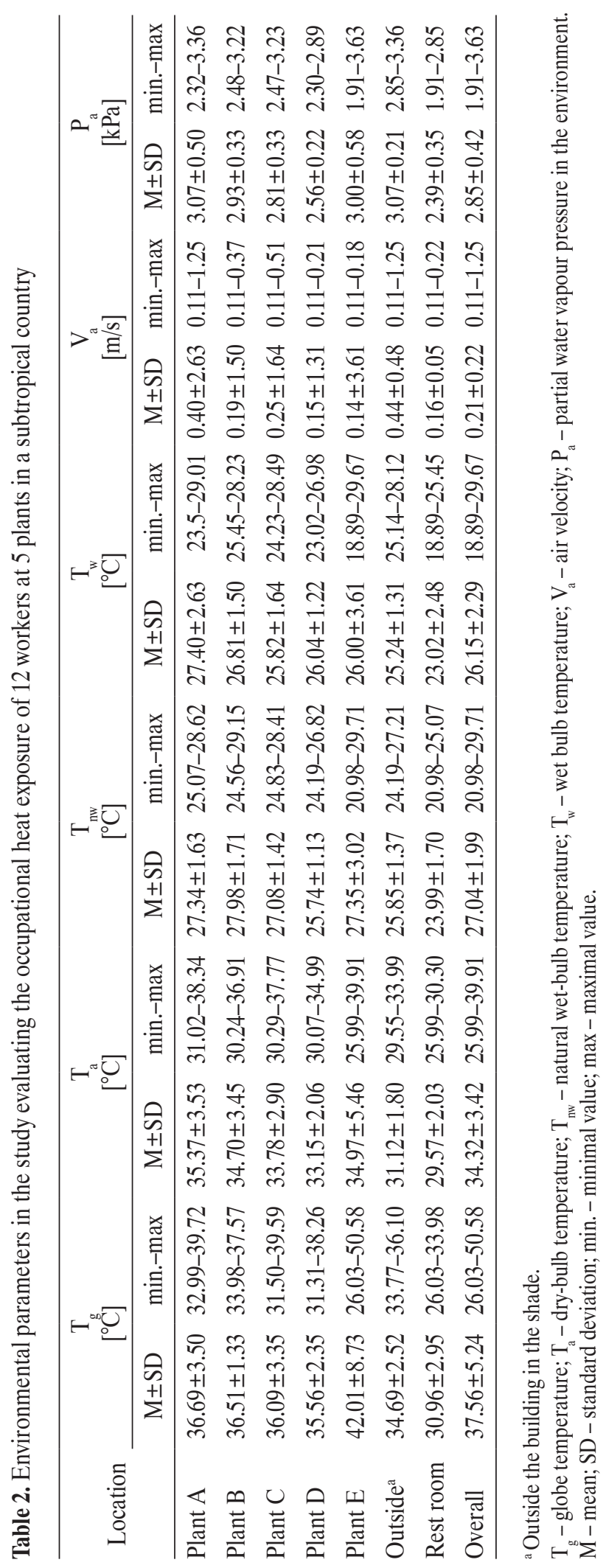


Table 3. Regression analysis results between wet bulb globe temperature (WBGT) and various heat stress indices in the study evaluating the occupational heat exposure of 12 workers at 5 plants in a subtropical country $(\mathrm{N}=29)$

\begin{tabular}{lcc}
\hline \multicolumn{1}{c}{ Index } & Regression equation & Correlation coefficient $\left(\mathrm{r}^{2}\right)$ \\
\hline Effective temperature $^{\mathrm{a}}(\mathrm{ET})$ & $0.684 \times \mathrm{WBGT}+8.283$ & 0.83 \\
Equivalent temperature $^{\mathrm{b}}\left(\mathrm{T}_{\text {eq }}\right)$ & $1.609 \times \mathrm{WBGT}-11.957$ & 0.94 \\
Corrected effective temperature $^{\mathrm{c}}(\mathrm{CET})$ & $0.856 \times \mathrm{WBGT}+4.280$ & 0.95 \\
Operative temperature $^{\mathrm{d}}\left(\mathrm{T}_{\mathrm{o}}\right)$ & $1.620 \times \mathrm{WBGT}-11.829$ & 0.93 \\
Oxford index $^{\mathrm{e}}(\mathrm{WD})$ & $0.729 \times \mathrm{WBGT}+5.370$ & 0.74 \\
Discomfort index $^{\mathrm{f}}(\mathrm{DI})$ & $0.892 \times \mathrm{WBGT}+3.326$ & 0.84 \\
Fighter index of thermal stress $^{\mathrm{g}}(\mathrm{FITS})$ & $0.941 \times \mathrm{WBGT}+10.413$ & 0.79 \\
Modified discomfort index $^{\mathrm{h}}(\mathrm{MDI})$ & $0.832 \times \mathrm{WBGT}+4.813$ & 0.79 \\
Environmental stress index $^{\mathrm{i}}(\mathrm{ESI})$ & $0.808 \times \mathrm{WBGT}+5.333$ & 0.73 \\
Wet-bulb dry temperature $^{\mathrm{j}}(\mathrm{WBDT})$ & $0.939 \times \mathrm{WBGT}+2.740$ & 0.86 \\
Relative humidity dry temperature $^{\mathrm{k}}(\mathrm{RHDT})$ & $0.845 \times \mathrm{WBGT}+10.563$ & 0.79 \\
\hline
\end{tabular}

${ }^{a}$ ET was estimated from psychrometric charts using an Assmann psychrometer.

${ }^{\mathrm{b}} \mathrm{T}_{\mathrm{eq}}=0.55 \times \mathrm{T}_{\mathrm{a}}+0.45 \times \mathrm{T}_{\mathrm{r}}+\left[\left(0.24-0.75 \times \mathrm{V}_{\mathrm{a}} 0.5\right)\left(36.5-\mathrm{T}_{\mathrm{a}}\right)\right] /(1+\mathrm{Icl})$, Generally, during summer, the workers might be wearing light trousers and short-sleeve shirt or T-shirt, with approximate clothing insulation (Icl) of 0.4 clo.

${ }^{\mathrm{c}} \mathrm{CET}$ was estimated from psychrometric charts using an Assmann psychrometer, or CET $=0.786 \times \mathrm{WBGT}+6.0$.

${ }^{\mathrm{d}} \mathrm{T}_{\mathrm{o}}=\left(0.45+0.25 \times \mathrm{V}_{\mathrm{a}}\right) \times \mathrm{T}_{\mathrm{a}}+\left[1-\left(0.45+0.25 \times \mathrm{V}_{\mathrm{a}}\right)\right] \times \mathrm{T}_{\mathrm{r}}$.

${ }^{\mathrm{e}} \mathrm{WD}=0.85 \times \mathrm{T}_{\mathrm{nw}}+0.15 \times \mathrm{T}_{\mathrm{a}}$.

${ }^{\mathrm{f}} \mathrm{DI}=0.5 \times \mathrm{T}_{\mathrm{nw}}+0.5 \times \mathrm{T}_{\mathrm{a}}$.

${ }^{\mathrm{g}}$ FITS $=0.83 \times \mathrm{T}_{\mathrm{nw}}+0.35 \mathrm{~T}_{\mathrm{a}}+5.08$.

${ }^{\mathrm{h}} \mathrm{MDI}=0.75 \times \mathrm{T}_{\mathrm{nw}}+0.3 \times \mathrm{T}_{\mathrm{a}}$.

${ }^{\mathrm{i}} \mathrm{ESI}=0.63 \times \mathrm{T}_{\mathrm{a}}-0.03 \mathrm{RH}(\%)+0.002 \mathrm{SR}+0.0054(\mathrm{~T} \times \mathrm{RH}(\%))-0.073 /(0.1+\mathrm{SR})$, where $\mathrm{RH}(\%)$ is relative humidity and SR is solar radiation.

j $\mathrm{WBDT}=0.4 \times \mathrm{T}_{\mathrm{nw}}+0.6 \times \mathrm{T}_{\mathrm{a}}$.

${ }^{\mathrm{k}} \mathrm{RHDT}=0.9 \times \mathrm{T}_{\mathrm{a}}+0.1 \times \mathrm{RH}(\%)$.

Other abbreviations as in Table 2.

coefficients $\left(r^{2}\right)$. Significant correlations were found between various heat-stress indices and the WBGT index, with $r^{2}$ values of $0.73-0.95$. Highly significant correlations were observed between the WBGT index and the $\mathrm{T}_{\mathrm{eq}}\left(\mathrm{r}^{2}=0.94\right)$, CET $\left(\mathrm{r}^{2}=0.95\right)$, and $\mathrm{T}_{\mathrm{o}}\left(\mathrm{r}^{2}=0.93\right)$. In addition, there was also a highly significant relationship between the ET and DI values ( $\left.\mathrm{r}^{2}=0.93\right)$, as illustrated in the Figure 1. This was consistent with previous results [37].

\section{Correlation between heat-stress indices and meteorological parameters}

To investigate the effects of meteorological parameters on heat-stress indices, the WBGT, $\mathrm{T}_{\mathrm{eq}}, \mathrm{CET}$, and $\mathrm{T}_{\mathrm{o}}$ values were related to environmental parameters $\left(\mathrm{T}_{\mathrm{a}}, \mathrm{T}_{\mathrm{r}}, \mathrm{P}_{\mathrm{a}}, \mathrm{V}_{\mathrm{a}}\right)$.
The data in the Tables 2 and 3 was subjected to the regression analysis, and these results are listed in the Table 4 . Correlations and regressions between the 4 different meteorological parameters and the heat-stress indices $(\mathrm{p}<0.05)$ were performed as described in the "Statistical analysis." Clearly, the WBGT and CET values were primarily responsive to the $\mathrm{T}_{\mathrm{a}}\left(\mathrm{r}^{2}=0.86\right.$ and $\mathrm{r}^{2}=0.87$, respectively).

The linear relationships for the WBGT and CET values to the $\mathrm{T}_{\mathrm{r}}\left(\mathrm{r}^{2}=0.81\right.$ and $\mathrm{r}^{2}=0.8$, respectively $)$ were less pronounced than for $\mathrm{T}_{\mathrm{a}}$, but they were still evident. Also clearly evident was that the $T_{e q}$ and $T_{0}$ values were primarily responsive to the $T_{r}\left(r^{2}=0.91\right.$ and $r^{2}=0.94$, respectively $)$, while, even though the correlations of the $\mathrm{T}_{\mathrm{eq}}$ and $\mathrm{T}_{\mathrm{o}}$ values 


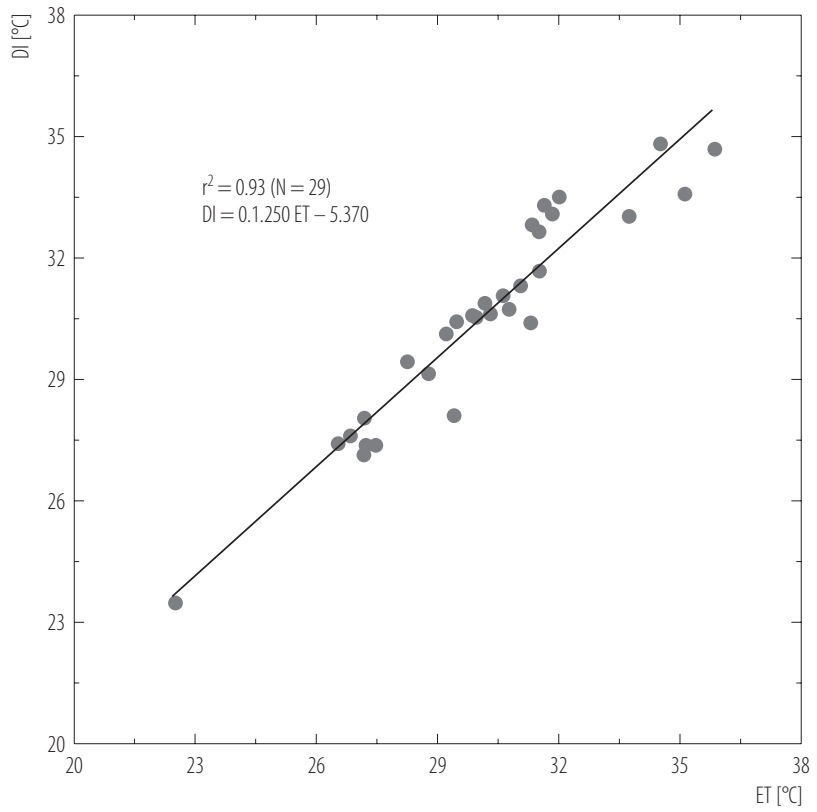

$\mathrm{r}^{2}-$ correlation coefficient.

$\mathrm{N}$ - number of samples.

Fig. 1. Regression between the discomfort index (DI) and effective temperature (ET) values at each measurement site in the study evaluating the occupational heat exposure of 12 workers at 5 plants in a subtropical country with $\mathrm{T}_{\mathrm{a}}\left(\mathrm{r}^{2}=0.83\right.$ and $\mathrm{r}^{2}=0.78$, respectively) were less pronounced than for $\mathrm{T}_{\mathrm{r}}$, they were still evident (Table 4). Ambient water vapor pressure was not as highly correlated with these indices, with $r^{2}$ values of $0.44-0.62$. It was also evident that, despite the wide range in these indices, no direct relationship or correlation between these indices and the $\mathrm{V}_{\mathrm{a}}$ was found (Table 4).

\section{Workers' time-weighted average heat-stress indices}

The time-motion study was done to understand the operation characteristics (work time, rest time, clothing, etc.) of each worker. At each of the surveyed plants, the operation characteristics were monitored during the work shift to calculate the time-weighted average heat level and the time-weighted average metabolic rate to which each worker was exposed. The Table 5 summarizes the values of the time-weighted average heart rate, metabolic rate, WBGT, CET and HSI.

The mean values of the WBGT, CET and HSI, were 28.86 \pm $1.15^{\circ} \mathrm{C}, 29.03 \pm 1.04^{\circ} \mathrm{C}$, and $107.99 \pm 50 \%$, respectively.

Table 4. Regression analysis results between various heat stress indices and environmental parameters in the study evaluating the occupational heat exposure of 12 workers at 5 plants in a subtropical country $(\mathrm{N}=29)$

\begin{tabular}{lccc}
\hline \multicolumn{1}{c}{ Index } & Parameters & Regression equation & Correlation coefficient $\left(\mathrm{r}^{2}\right)$ \\
\hline WBGT & $\left.\mathrm{T}_{\mathrm{a}}{ }^{\circ} \mathrm{C}\right]$ & $0.769 \times \mathrm{T}_{\mathrm{a}}+3.774$ & 0.860 \\
& $\left.\mathrm{~T}_{\mathrm{r}}{ }^{\circ} \mathrm{C}\right]$ & $0.389 \times \mathrm{T}_{\mathrm{r}}+14.689$ & 0.810 \\
& $\mathrm{P}_{\mathrm{a}}[\mathrm{kPa}]$ & $4.659 \times \mathrm{P}_{\mathrm{a}}+16.861$ & 0.490 \\
CET & $\mathrm{V}_{\mathrm{a}}[\mathrm{m} / \mathrm{s}]$ & $-0.654 \times \mathrm{V}_{\mathrm{a}}+30.396$ & 0.003 \\
& $\left.\mathrm{~T}_{\mathrm{a}}{ }^{\circ} \mathrm{C}\right]$ & $0.6754 \times \mathrm{T}_{\mathrm{a}}+6.931$ & 0.870 \\
& $\left.\mathrm{~T}_{\mathrm{r}}{ }^{\circ} \mathrm{C}\right]$ & $0.336 \times \mathrm{T}_{\mathrm{r}}+16.770$ & 0.800 \\
& $\mathrm{P}_{\mathrm{a}}[\mathrm{kPa}]$ & $4.557 \times \mathrm{P}_{\mathrm{a}}+17.118$ & 0.620 \\
& $\mathrm{~V}_{\mathrm{a}}[\mathrm{m} / \mathrm{s}]$ & $-0.550 \times \mathrm{V}_{\mathrm{a}}+30.239$ & 0.002 \\
$\mathrm{~T}_{\mathrm{eq}}$ & $\left.\mathrm{T}_{\mathrm{a}}{ }^{\circ} \mathrm{C}\right]$ & $1.247 \times \mathrm{T}_{\mathrm{a}}-15.608$ & 0.830 \\
& $\left.\mathrm{~T}_{\mathrm{r}}{ }^{\circ} \mathrm{C}\right]$ & $0.684 \times \mathrm{T}_{\mathrm{r}}+9.371$ & 0.910 \\
& $\mathrm{P}_{\mathrm{a}}[\mathrm{kPa}]$ & $7.387 \times \mathrm{P}_{\mathrm{a}}+15.501$ & 0.450 \\
& $\mathrm{~V}_{\mathrm{a}}[\mathrm{m} / \mathrm{s}]$ & $-1.958 \times \mathrm{V}_{\mathrm{a}}+36.992$ & 0.008 \\
$\mathrm{~T}_{\mathrm{o}}$ & $\left.\mathrm{T}_{\mathrm{a}}{ }^{\circ} \mathrm{C}\right]$ & $1.227 \times \mathrm{T}_{\mathrm{a}}-5.101$ & 0.780 \\
& $\left.\mathrm{~T}_{\mathrm{r}}{ }^{\circ} \mathrm{C}\right]$ & $0.703 \times \mathrm{T}_{\mathrm{r}}+9.057$ & 0.940 \\
& $\mathrm{P}_{\mathrm{a}}[\mathrm{kPa}]$ & $7.394 \times \mathrm{P}_{\mathrm{a}}+15.928$ & 0.440 \\
& $\mathrm{~V}_{\mathrm{a}}[\mathrm{m} / \mathrm{s}]$ & $-2.192 \times \mathrm{V}_{\mathrm{a}}+37.484$ & 0.010 \\
\hline
\end{tabular}


Table 4. Regression analysis results between various heat stress indices and environmental parameters in the study evaluating the occupational heat exposure of 12 workers at 5 plants in a subtropical country $(\mathrm{N}=29)$ - cont.

\begin{tabular}{cccc}
\hline \multicolumn{1}{c}{ Index } & Parameters & Regression equation & Correlation coefficient $\left(\mathrm{r}^{2}\right)$ \\
\hline HSI $^{\mathrm{a}}$ & $\left.\mathrm{T}_{\mathrm{a}}{ }^{\circ} \mathrm{C}\right]$ & $9.267 \times \mathrm{T}_{\mathrm{a}}-203.631$ & 0.640 \\
& $\left.\mathrm{~T}_{\mathrm{r}}{ }^{\circ} \mathrm{C}\right]$ & $4.530 \times \mathrm{T}_{\mathrm{r}}-65.936$ & 0.560 \\
& $\mathrm{P}_{\mathrm{a}}[\mathrm{kPa}]$ & $52.183 \times \mathrm{P}_{\mathrm{a}}-34.892$ & 0.310 \\
& $\mathrm{~V}_{\mathrm{a}}[\mathrm{m} / \mathrm{s}]$ & $42.707 \times \mathrm{V}_{\mathrm{a}}+105.376$ & 0.060 \\
\hline
\end{tabular}

WBGT - wet bulb globe temperature; HSI - heat stress index; $\mathrm{T}_{\mathrm{r}}$ - mean radiant temperature. Other abbreviations as in Table 3 .

${ }^{a}$ Light activity, M = 213 Watt (recommended by the International Organization for Standardization - ISO 7243 [2]).

The limited values of the WBGT and CET were judged from the published literatures $[1,2,9]$. According to Brotherhood [13], an HSI of 100 is considered to be the limit that an average person can work for $8 \mathrm{~h}$ without danger of heat strain. This data (Table 5) shows that $42 \%$ (5 workers, $\left.\mathrm{WBGT}_{\mathrm{TWA}_{\mathrm{A}}}>\mathrm{WBGT}_{\text {limit }}\right), 42 \%$ (5 workers, $\mathrm{CET}_{\mathrm{TWA}}>$ $\mathrm{CET}_{\text {limit }}$ ) and $58 \%$ (7 workers, HIS $>100 \%$ ) of the subjects exceeded the recommended limits of the WBGT, CET and HSI, respectively. The comparison of different heat stress indices (WBGT, CET and HSI) showed that the WBGT index appeared to match the CET value, while the heat strain was overestimated by the HSI.

Furthermore, the limits for acclimatized subjects, $\mathrm{D}_{\text {limloss } 50}$ (maximum water loss of $7.5 \%$ of the body mass) are reported in the Figure 2a, where the duration of the limited exposure time is plotted against the time-weighted average $\mathrm{WBGT}$ index $\left(\mathrm{WBGT}_{\mathrm{TWA}}\right)$. A model has also been proposed by Holmér who used the WBGT index for predicting the allowable exposure time [40]. To make a comparison, the duration of the limited exposure time predicted by the Holmér model (WBGT model) and that predicted by the HIS model [13] are presented in the Figure $2 b$. In these conditions, according to the WBGT model $42 \%$ of the workers should not work continuously, and $58 \%$ and $42 \%$ of the subjects should not continue working in the hot environments, as predicted by the HSI and PHS index (ISO 7933 index, 2004) [4], respectively. However, further studies on different heat environments

Table 5. Time-weighted average parameters for each worker in the study evaluating the occupational heat exposure of 12 workers at 5 plants in a subtropical country

\begin{tabular}{lcc}
\hline \multicolumn{1}{c}{ Parameter } & $\mathrm{M} \pm \mathrm{SD}$ & Range \\
\hline $\mathrm{HR}[\mathrm{bpm}]$ & $91 \pm 10.2$ & $83-108$ \\
$\mathrm{M}_{\mathrm{TWA}}{ }^{\mathrm{a}}[\mathrm{Watt}]$ & $247.93 \pm 68.75$ & $153.52-312.86$ \\
$\mathrm{WBGT}_{\mathrm{TWA}}{ }^{\circ}\left[{ }^{\circ} \mathrm{C}\right]$ & $28.86 \pm 1.15$ & $27.62-30.81$ \\
$\mathrm{CET}{ }_{\mathrm{TWA}}{ }^{\mathrm{a}}\left[{ }^{\circ} \mathrm{C}\right]$ & $29.03 \pm 1.04$ & $27.54-30.75$ \\
$\mathrm{HSI}_{\mathrm{TWA}}{ }^{a}[\%]$ & $107.99 \pm 50.00$ & $49.30-182.68$ \\
\hline
\end{tabular}

HR - heart rate; TWA - time-weighted average. Other abbreviations as in Tables 3 and 4.

${ }^{\mathrm{a}} \mathrm{A}_{\mathrm{TWA}}$ is the time-weighted average parameters:

$\mathrm{A}_{\mathrm{TWA}}=\frac{\sum \mathrm{A} \times \mathrm{t}_{\mathrm{i}}}{\sum \mathrm{t}_{\mathrm{i}}}$

where $t_{i}$ is the exposure time of worker at every test point and $\Sigma t_{i}$ is the total exposure time of worker. 

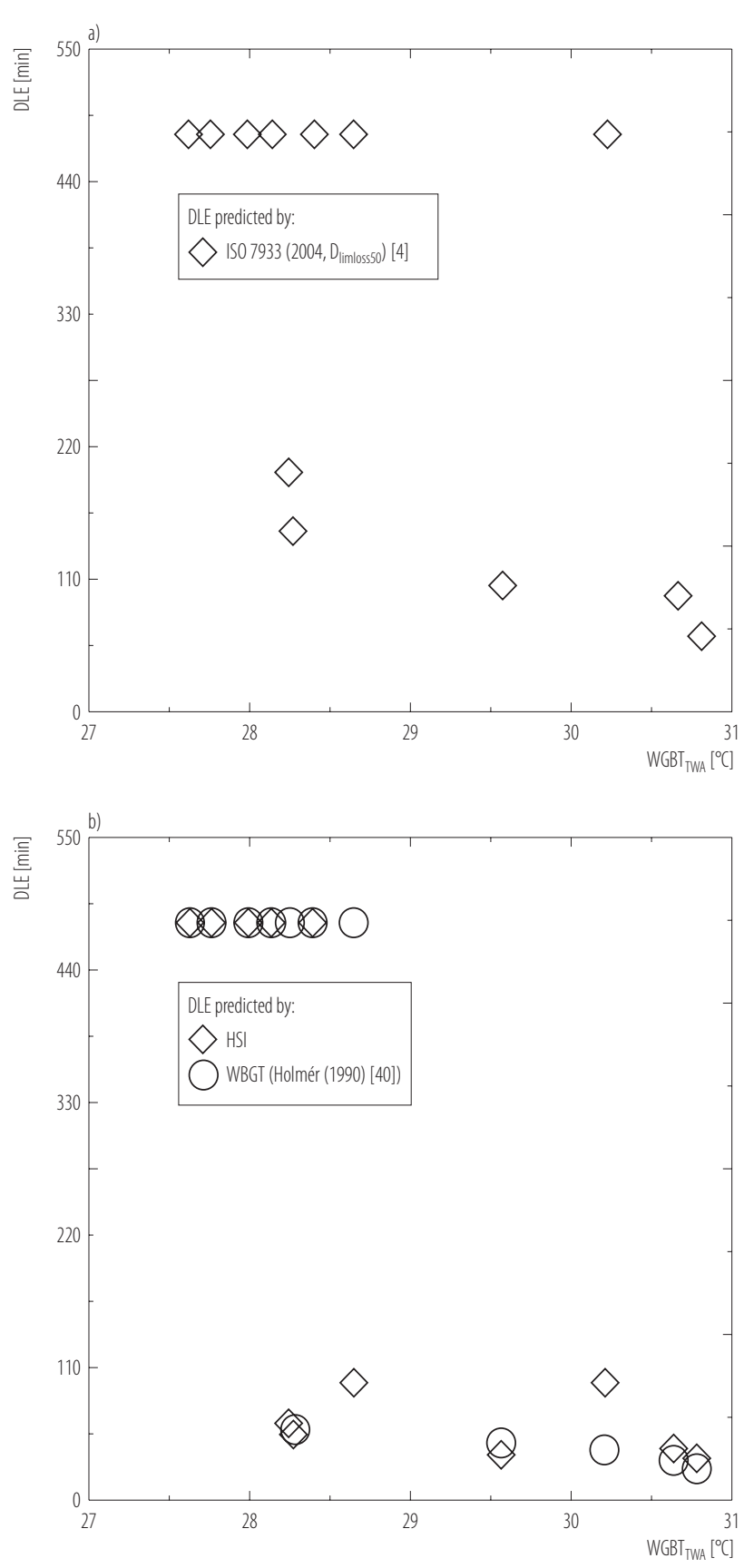

WBGT - wet bulb globe temperature; TWA - time-weighted average; DLE - duration-limited exposure time; PHS - predicted heat strain; HIS - heat stress indexes.

Fig. 2. The time-weighted average WBGT index for each worker in relation to the DLE estimated from various models: a) DLE was predicted by PHS index; b) DLE was predicted by HSI and WBGT - in the study evaluating the occupational heat exposure of 12 workers at 5 plants in a subtropical country and more subjects should be performed. Furthermore, the tolerance times predicted by the ISO 7933 standard [4,41], HSI [13] and WBGT model [40] were also related to the difference between the time-weighted average WBGT index $\left(\mathrm{WBGT}_{\text {TWA }}\right)$ and the $\mathrm{WBGT}_{\text {limit }}$. Correlations and regressions between the tolerance times predicted by the 3 models and the difference between the time-weighted average WBGT index $\left(\mathrm{WBGT}_{\mathrm{TWA}_{\mathrm{A}}}\right)$ and the $\mathrm{WBGT}_{\text {limit }}(\mathrm{p}<0.05)$ were performed as described in the "Statistical analysis." A positive difference between the time-weighted average WBGT index $\left(\mathrm{WBGT}_{\mathrm{TWA}}\right)$ and the $\mathrm{WBGT}_{\text {limit }}$ indicates that the job may not be performed continuously. A negative value (WBGT $\mathrm{TWA}_{\mathrm{TA}}-\mathrm{WBGT}_{\text {limit }}$ ) indicates that the heat load was below the recommended values. For each model, the exponential regression equation and correlation coefficients $\left(\mathrm{r}^{2}\right)$ are given in the Table 6 . For the 3 indices examined, the HIS value, PHS index (ISO 7933, 2004) [4] and WBGT model, these correlation coefficients $\left(\mathrm{r}^{2}\right)$ were $0.93,0.61$ and 0.71 , respectively.

\section{Correlation between the various heat-stress indices and the physiological responses}

Using the data in the Table 5, the data of time-motion study and the $\mathrm{T}_{\mathrm{r}}$ (equation (1)), the values of time-weighted average heat-stress indices were determined. Correlations and regressions between the time-weighted average heatstress indices and the time-weighted average HR were carried out using Tukey's method with a significance level of $p<0.05$ using 2010 Microsoft Office Excel and Origin version 6.1 software. The correlation of the various heatstress indices with the time-weighted average HR (bpm) for each subject is given in the Table 7 .

The heart rate was not significantly correlated with these meteorological indices, with $\mathrm{r}^{2}$ values of $0.29-0.57$. The worker's duration-limited exposure times (predicted by ISO 7933 [4]) obtained in this study were in accordance to some extent with those obtained by HR $\left(\mathrm{r}^{2}=0.58\right)$. A significant correlation was also found between the HR 
Table 6. Regression analysis results between $\mathrm{WBGT}_{\mathrm{TWA}}-\mathrm{WBGT}_{\text {limit }}{ }^{\mathrm{a}}$ and worker's DLE predicated by HSI criteria, ISO 7933 standard ${ }^{\mathrm{b}}$ and WBGT criteriac in the study evaluating the occupational heat exposure of 12 workers at 5 plants in a subtropical country

\begin{tabular}{|c|c|c|}
\hline Index & Regression equation & Correlation coefficient $\left(\mathrm{r}^{2}\right)$ \\
\hline HSI & $\operatorname{DLE}[\mathrm{min}]=74.836 \times \mathrm{e}^{-0.444\left(\mathrm{WBGT}_{\mathrm{TWA}}-\mathrm{WBGT}_{\text {limit }}\right)}$ & 0.93 \\
\hline ISO 7933 & $\mathrm{DLE}[\mathrm{min}]=199.098 \times \mathrm{e}^{-0.231\left(\mathrm{WBGT}_{\mathrm{TWA}}-\mathrm{WBGT} \text { limit) }\right.}$ & 0.61 \\
\hline WBGT & $\operatorname{DLE}[\min ]=92.617 \times \mathrm{e}^{-0.442\left(\mathrm{WBGT}_{\mathrm{TWA}}-\mathrm{WBGT} \text { limit }\right)}$ & 0.71 \\
\hline
\end{tabular}

${ }^{a} \mathrm{WBGT}_{\text {limit }}$ recommended by the International Organization for Standardization - ISO 7243 [2].

${ }^{b}$ Obtained from ISO 7933 (2004) [4], $\mathrm{D}_{\text {limloss } 0}$ (maximum water loss of $7.5 \%$ of the body mass).

c Proposed by Holmér (1998) [40].

DLE - duration limited exposure time, HSI - heat stress index.

Other abbreviations as in Tables 4 and 5 .

and the difference between $\mathrm{WBGT}_{\mathrm{TWA}}$ and WBGT limit $\left(r^{2}=0.86\right)$ (Table 7). Furthermore, the time-weighted average skin temperature predicted by the ISO 7933 [4] for each subject was also related to the time-weighted average heat-stress indices. The analysis of variance (ANOVA) was carried out using Tukey's method with a significance level of $p<0.05$ using 2010 Microsoft Office Excel and Origin version 6.1 software.

The Table 8 shows the correlations of the various heat-stress indices with the time-weighted average skin temperature predicted by the ISO 7933 [4] for each subject. The mean skin temperature was strongly responsive to these meteorological indices (WBGT, ET, CET, $\left.\mathrm{T}_{\text {eq }}, \mathrm{T}_{\mathrm{o}}\right)\left(\mathrm{r}^{2}=0.77-\right.$ 0.96), indicating that the mean skin temperature increased as the meteorological index increased. Increasing the timeweighted average HIS $\left(\mathrm{r}^{2}=0.89\right)$ and $\mathrm{SW}_{\text {req }}\left(\mathrm{r}^{2}=0.93\right)$ values also led to higher mean skin temperatures (Table 8). In this study, there was also a highly significant relationship between tolerance times and mean skin temperatures $\left(\mathrm{r}^{2}=0.76\right)$ (Table 8$)$. Additionally, there was

Table 7. Correlation of various heat stress indices with the time-weighted average heart rate (HR [bpm]) for each worker in the study evaluating the occupational heat exposure of 12 workers at 5 plants in a subtropical country

\begin{tabular}{|c|c|c|}
\hline Index & Regression equation & Correlation coefficient $\left(\mathrm{r}^{2}\right)$ \\
\hline WBGT $\left[{ }^{\circ} \mathrm{C}\right]$ & $\mathrm{HR}=15.625$ WBGT-352.641 & 0.33 \\
\hline $\mathrm{ET}\left[{ }^{\circ} \mathrm{C}\right]$ & $\mathrm{HR}=16.994 \mathrm{ET}-381.678$ & 0.29 \\
\hline $\mathrm{CET}\left[{ }^{\circ} \mathrm{C}\right]$ & $\mathrm{HR}=16.949 \mathrm{CET}-394.695$ & 0.29 \\
\hline $\mathrm{T}_{\mathrm{eq}}\left[{ }^{\circ} \mathrm{C}\right]$ & $\mathrm{HR}=9.346 \mathrm{~T}_{\mathrm{eq}}-225.869$ & 0.56 \\
\hline $\mathrm{T}_{0}\left[{ }^{\circ} \mathrm{C}\right]$ & $\mathrm{HR}=10.417 \mathrm{~T}_{0}-266.979$ & 0.57 \\
\hline $\mathrm{T}_{\mathrm{sk}}\left[{ }^{\circ} \mathrm{C}\right]$ & $\mathrm{HR}=40.000 \mathrm{~T}_{\mathrm{sk}}-1318.960$ & 0.64 \\
\hline HSI [\%] & $\mathrm{HR}=0.222 \mathrm{HSI}+74.203$ & 0.84 \\
\hline $\mathrm{SW}_{\text {req }}[\mathrm{g} / \mathrm{h}]$ & $\mathrm{HR}=0.019 \mathrm{SW}_{\text {req }}+81.576$ & 0.52 \\
\hline $\operatorname{DLE}^{a}($ ISO 7933) [min] & $\mathrm{HR}=-0.072 \mathrm{DLE}($ ISO 7933) +122.049 & 0.58 \\
\hline $\mathrm{WBGT}_{\mathrm{TWA}}-\mathrm{WBGT}_{\text {limit }}{ }^{\mathrm{b}}\left[{ }^{\circ} \mathrm{C}\right]$ & $\mathrm{HR}=4.167\left(\mathrm{WBGT}_{\mathrm{TWA}}-\mathrm{WBGT}_{\text {limit }}\right)+103.646$ & 0.86 \\
\hline
\end{tabular}

$\mathrm{SW}_{\text {req }}$ - required sweat rate. Other abbreviations as in Tables 3-6.

${ }^{a}$ Obtained from the International Organization for Standardization - ISO 7933 (2004) [4], $\mathrm{D}_{\text {limloss50 }}$ (maximum water loss of $7.5 \%$ of the body mass).

${ }^{\mathrm{b}} \mathrm{WBGT}_{\text {limit }}$ recommended by ISO 7243 [2]. 
Table 8. Relationship between various heat stress indices and the time-weighted average skin temperature $\left(\mathrm{T}_{\mathrm{sk}}\left[{ }^{\circ} \mathrm{C}\right]\right)$ for each worker in the study evaluating the occupational heat exposure of 12 workers at 5 plants in a subtropical country

\begin{tabular}{|c|c|c|}
\hline Index & Regression equation & Correlation coefficient $\left(\mathrm{r}^{2}\right)$ \\
\hline WBGT $\left[{ }^{\circ} \mathrm{C}\right]$ & $\mathrm{T}_{\mathrm{sk}}=0.309 \mathrm{WBGT}+26.500$ & 0.80 \\
\hline $\mathrm{ET}\left[{ }^{\circ} \mathrm{C}\right]$ & $\mathrm{T}_{\mathrm{sk}}=0.303 \mathrm{ET}+26.819$ & 0.86 \\
\hline $\mathrm{CET}\left[{ }^{\circ} \mathrm{C}\right]$ & $\mathrm{T}_{\mathrm{sk}}=0.346 \mathrm{CET}+25.373$ & 0.77 \\
\hline $\mathrm{T}_{\mathrm{eq}}\left[{ }^{\circ} \mathrm{C}\right]$ & $\mathrm{T}_{\mathrm{sk}}=0.221 \mathrm{~T}_{\mathrm{eq}}+27.762$ & 0.96 \\
\hline $\mathrm{T}_{0}\left[{ }^{\circ} \mathrm{C}\right]$ & $\mathrm{T}_{\mathrm{sk}}=0.250 \mathrm{~T}_{\mathrm{o}}+26.648$ & 0.94 \\
\hline HSI [\%] & $\mathrm{T}_{\mathrm{sk}}=6.705 \times 10^{-3} \mathrm{HSI}+34.689$ & 0.89 \\
\hline $\mathrm{SW}_{\text {req }}[\mathrm{g} / \mathrm{h}]$ & $\mathrm{T}_{\mathrm{sk}}=3.790 \times 10^{-3} \mathrm{SW}_{\mathrm{req}}+35.043$ & 0.93 \\
\hline DLE $^{a}($ ISO 7933) [min] & $\mathrm{T}_{\mathrm{sk}}=38.001-0.645 \mathrm{Ln}(\mathrm{DLE}($ ISO 7933)) & 0.76 \\
\hline $\mathrm{WBGT}_{\mathrm{TWA}}-\mathrm{WBGT}_{\text {limit }}{ }^{\mathrm{b}}\left[{ }^{\circ} \mathrm{C}\right]$ & $\mathrm{T}_{\mathrm{sk}}=0.128\left(\mathrm{WBGT}_{\mathrm{TWA}}-\mathrm{WBGT}_{\text {limit }}\right)+35.569$ & 0.88 \\
\hline
\end{tabular}

Abbreviations as in Tables 3-7.

a Obtained from the International Organization for Standardization - ISO 7933 (2004) [4], $\mathrm{D}_{\text {limosss }}$ (maximum water loss of 7.5\% of the body mass).

${ }^{b} \mathrm{WBGT}_{\text {limit }}$ recommended by ISO 7243 [2].

a significant relationship between the mean skin temperature and the $\mathrm{WBGT}_{\mathrm{TWA}}-\mathrm{WBGT}_{\text {limit }}\left(\mathrm{r}^{2}=0.88\right)$ (Table 8). These results indicate that skin temperature may be used for predicting whether a given environment is suitable for continuous work.

\section{DISCUSSION}

This paper describes a study of occupational heat exposure in 5 plants in Taiwan (subtropical country). The WBGT values ranged $22.5-35.8^{\circ} \mathrm{C}$ for each of the work positions studied. The WBGT values observed in all locations in the heavy-oil power plants (plants A, B, C and D), except for the restrooms and reference locations, indicated that heat stress was moderate, with the mean WBGT being $30.73^{\circ} \mathrm{C}\left(87.31^{\circ} \mathrm{F}\right)$. Compared with the heavy-oil power plants, in the coal-fueled power plant (plant $\mathrm{E}$ ), heat stress was severe, with the mean WBGT of $34.08^{\circ} \mathrm{C}\left(93.34^{\circ} \mathrm{F}\right)$. Notably, outside the building in the shade, the dry-bulb air temperatures varied from $29.55^{\circ} \mathrm{C}$ to $33.99^{\circ} \mathrm{C}$. They ranged $27.13-29.88^{\circ} \mathrm{C}\left(80.83-85.8^{\circ} \mathrm{F}\right)$, with a mean level of $28.5^{\circ} \mathrm{C}\left(83.3^{\circ} \mathrm{F}\right)$ WBGT. The results indicate that the heat stress that occurs naturally due to the hot climate in coastal areas of Taiwan during the summer months was considerable for the workers. Furthermore, the hot climatic conditions in summer directly influence the occurrence of heat-related illnesses such as heat edema, heat syncope, heat cramps, heat exhaustion and heat stroke.

Epstein and Moran [37] reported that the values calculated by the WD, DI, FITS, MDI, and WBDT indices strongly correlated with the WBGT index, with $\mathrm{r}^{2}$ values that ranged 0.93-0.967. In this study, the coefficients of determination $\left(\mathrm{r}^{2}\right)$ evaluated for the 5 indices were less than those reported in the literature (with $\mathrm{r}^{2}$ values of 0.74-0.86) (Table 3). According to Wallace et al. [42], the RHDT index, due to its easily attainable components, would also be very beneficial for training situations outside the military. As it may be seen from the Table 3, the RHDT index showed a significant correlation $\left(r^{2}=0.79\right)$ with the WBGT index in this study.

Moran and Epstein [23] presented evidence that applying the ESI to the pooled Israeli databases from various environments showed a strong correlation $\left(\mathrm{r}^{2}=0.96-0.99\right)$ with the WBGT. Our value $\left(r^{2}=0.73\right)$ was smaller than those found by other authors. Additionally, the ET index was obtained by referring measured dry bulb temperature, 
wet bulb temperature and air velocity to a nomographs. In this study, there was a moderate correlation $\left(r^{2}=0.83\right)$ between the ET and WBGT for all of the treatments. A previous study performed by Yaglou and Minard [6] showed that the WBGT index was developed as a direct measurement of the CET index. Furthermore, the Japan Society for Occupation Health (JSOH) recommendation contained the following regression equation [9]:

$$
\mathrm{CET}=0.786 \times \mathrm{WBGT}+6\left({ }^{\circ} \mathrm{C}\right)
$$

where:

CET - corrected effective temperature, WBGT - wet bulb globe temperature.

The correlation equation predicted by this study was in good agreement with that reported by the Japan Society for Occupation Health (Figure 1). In addition, Sohar et al. [24] reported a strong correlation between the DI and the WGBT index $\left(r^{2}=0.95\right)$. Our value $\left(r^{2}=0.84\right)$ was lower than the one reported by Sohar et al. [24]. In addition, Epstein and Moran [37] also stated that the DI values were very similar to the ET values. This result was demonstrated in this study, as depicted in this Figure $1\left(r^{2}=0.93\right)$.

The operative temperature $\left(\mathrm{T}_{0}\right)$ index was modified by Gagge and Nishi [43] and was covered by ISO 7730 [29]. In 1979, Madsen [28] modified the equivalent temperature $\left(\mathrm{T}_{\mathrm{eq}}\right)$ index, and wrote an equation that included the influence of clothing on readings. In this study, the $\mathrm{T}_{\mathrm{o}}$ and $\mathrm{T}_{\mathrm{eq}}$ indices were also found to be significantly correlated with the WGBT index ( $\mathrm{r}^{2}=0.93$ and 0.94 , respectively), as depicted in the Table 3.

The relationships of various heat stress criteria to the 4 factors $\left(T_{a}, T_{r}, P_{a}, V_{a}\right)$ in this study for each of experimental conditions are shown in the Table 4. The influence of relative humidity was not significant $\left(\mathrm{r}^{2}=0.31-0.62\right)$ but these indices increased as the $T_{a}\left(r^{2}=0.49-0.87\right)$ and $\mathrm{T}_{\mathrm{r}}\left(\mathrm{r}^{2}=0.56-0.91\right)$ increased. These indices had no direct relationship or correlation with $\mathrm{V}_{\mathrm{a}}$ (Table 4).

The Table 5 depicts the means and ranges of the timeweighted average WBGT, CET and HIS values during the study for each subject. This data indicates that $42 \%$ of the subjects (5 workers) surpassed the limits of the WBGT and CET [2,9], and $58 \%$ of the subjects (7 workers) exceeded the limits of the HIS (100\%). Applying the PHS model to the assessment of heat load revealed that $42 \%$ of the acclimatized subjects were undergoing unacceptable physiological stress (water loss or body temperature). However, a more extensive sample of workers will enhance the scientific relevance for the different categories as for example age and specific professions in industry. The WBGT index and HSI also allowed for the calculation of an acceptable working time, as depicted in the Figure 2. Comparisons between the WBGT and PHS models suggested that the both criteria had similar effects on the heat risk. In addition, a comparison of the HSI and PHS models reveals that the HIS criteria tend to overestimate the heat load (7 workers).

However, the maximum allowable exposure time predicted by $\mathrm{D}_{\text {limloss } 0}$ (maximum water loss of $7.5 \%$ of the body mass) was the highest among the 3 methods. Moreover, Nag and Nag [44] stated that the relationship of tolerance time to the WBGT values was useful for estimating a protective limit for employees working in extremely hot environments. The exponential relationships between the duration-limited exposure time predicted by various criteria and the WBGT for each subject are given in the Table 6. A significant correlation was found between duration-limited exposure time and the $\mathrm{WBGT}_{\mathrm{TWA}}{ }^{-}$ $\mathrm{WBGT}_{\text {limit }}$ index $\left(\mathrm{r}^{2}=0.61-0.93\right)$. The tolerance times predicted by these models corresponded closely to the workrest schedules recommended by the American Conference of Governmental Industrial Hygienists (ACGIH) for moderate work. The 3 criteria overestimated the tolerance times for light metabolic demands but underestimated the tolerance times for heavy metabolic rates. 
The increase in heart rate due to heat strain was on average 33 beats per minute (bpm) per $1^{\circ} \mathrm{C}$ increase in core temperature; heart rate was adopted in the ISO 8996 [38] as the physiological parameter monitored. The American Conference of Governmental Industrial Hygienists also recommends that a time-weighted average for the day (8-h work shift) should not be greater than $115 \mathrm{bpm}$. Despite the wide range in the WBGT, time-weighted average heart rates (83108 bpm) were well below the level suggested as limiting by the ACGIH. However, the heart rate response to metabolic rate was much greater than that caused by environmental heat [32,33]. This study (Table 7) also found that heart rate was some extent correlated with duration-limited exposure times (predicted by the ISO 7933 [4]) $\left(\mathrm{r}^{2}=0.58\right)$ and the difference between $\mathrm{WBGT}_{\mathrm{TWA}}$ and $\mathrm{WBGT}_{\text {limit }}$ (recommended by JSOH [9]) $\left(\mathrm{r}^{2}=0.86\right)$. It may be used for estimating whether a given environment is suitable for continuous work.

Skin temperature is a very important heat transfer factor, and it directly affects energy transfer by convection and the evaporation of sweat [45]. A study by Iampietro [46] showed that skin temperature is a reliable and sensitive measure of the effect of hot and cold environments in humans. Additionally, according to the recommendations of some investigators, mean skin temperature is primarily a function of the ambient temperature and independent of the level of work $[46,47]$. In this study, the time-weight average skin temperature was predicted by the ISO 7933 [4]. As expected, the values for skin temperature predicted by the ISO 7933 [4] increased with increasing heat-stress indices (Table 8). A strong correlation exists between skin temperature and the $\mathrm{SW}_{\text {req }}$ index $\left(\mathrm{r}^{2}=0.93\right)$ (Table 8). This result suggests that this increase in the $\mathrm{SW}_{\text {req }}$ index was probably due to the increase in skin temperature. However, a study by Iampietro [46] also confirmed that a decrease in tolerance time is proportional to an increase in mean skin temperature. This was clearly seen in our experiments, as well $\left(\mathrm{r}^{2}=0.76\right)$ (Table 8).

\section{CONCLUSIONS}

To assess heat stress and strain in heavy-oil and coalfueled power plants, the ISO 7243 index (WBGT) and the ISO 7933 index (the maximum allowable exposure time, $\mathrm{D}_{\text {lim }}$ ) were used for assessing workers' heat loads. The WBGT values for the coal-fueled power plant were higher than those for the heavy-oil power plants. From the combination of the time-weight average WBGT values and metabolic rates for comparison against heat-stress limits in published literature, it was possible to evaluate whether a given environment was suitable for continuous work, and this method may also be used for constructing safe work-rest schedules. The WBGT levels exceeded reference values for $42 \%$ of the workers; therefore, a more detailed analysis was executed, providing the data to determine an acceptable working time.

Exposure durations and the resulting heat stress predicted by the ISO 7933 [4] produced that $42 \%$ of the acclimatized subjects were undergoing unacceptable physiological stress. The exponential relationship between workers' durationlimited exposure time, predicted by various estimated criteria, and WBGT were also found. The relationship between tolerance time and the WBGT values was useful for the instruction of workers in extremely hot environments and for ensuring their health and safety. Furthermore, the relationships between the values of various heat-stress indices and the WBGT index were also correlated in this study. Notwithstanding, further studies involving different hot environments and more subjects should be performed.

\section{ACKNOWLEDGEMENTS}

The authors would like to thank KMU colleagues (Li-Mei An, Shui-Chin Lu, Tin-Hsin Hsiao, Wen-Jeng Su, Yen-Jung Lee, Min-Yuan Hung) and students (Yi-Jing Jang, Mei-Jing Tseng, Shao-Yuan Hao, Fang-Yu Lin, Yei Ling Chong, Wai-Lun Lam, Chin-Wei Kuo) for technical and editorial assistance. Finally, the authors acknowledge the editors and referees for their constructive comments and encouragement. 


\section{REFERENCES}

1. International Organization for Standardization. ISO 7243:1989. Hot environments - Estimation of the heat stress on working man, based on the WBGT-index (wet bulb globe temperature). Geneva: The Organization; 1989.

2. International Organization for Standardization. ISO 7243:2003. Hot environments - Estimation of the heat stress on working man, based on the WBGT-index (wet bulb globe Temperature). Geneva: The Organization; 2003.

3. International Organization for Standardization. ISO 7933:1989. Hot environments - Analytical determination and interpretation of thermal stress using calculation of required sweat rate. Geneva: The Organization; 1989.

4. International Organization for Standardization. ISO 7933:2004. Ergonomics of the thermal environment - Analytical determination and interpretation of heat stress using calculation of the predicted heat strain. Geneva: The Organization; 2004.

5. World Health Organization. Health factors involved in working under conditions of heat stress. Technical Report Series No 412. Geneva: The Organization; 1969.

6. Yaglou CP, Minard D. Control of heat casualties at military training centers. AMA Arch Ind Health. 1957;16(4):302-16.

7. American Conference of Governmental Industrial Hygienists. Threshold limit values and biological exposure indices for chemical substances and physical agents. Cincinnati: The Conference; 2003.

8. National Institute for Occupational Safety and Health. Criteria for a recommended standard. Occupational exposure to hot environment. Washington: The Institute; 1986. p. 86-113.

9. Japan Society for Occupational Health. Recommendation of occupational exposure limits (2005-2006). J Occup Health. 2005;47:354-70.

10. Altinsoy H, Yildirim HA. Labor productivity losses over western Turkey in the twenty-first century as a result of alteration in WBGT. Int J Biometeorol. 2015;59(4):463-71, https://doi.org/10.1007/s00484-014-0863-z.
11. Bernard TE, Iheanacho I. Heat index and adjusted temperature as surrogates for wet bulb globe temperature to screen for occupational heat stress. J Occup Environ Hyg. 2015;12(5):323-33, https://doi.org/10.1080/15459624.2014. 989365.

12. Das B. Assessment of occupational health problems and physiological stress among the brick field workers of West Bengal, India. Int J Occup Med Environ Health. 2014;27(3): 413-25, https://doi.org/10.2478/s13382-014-0262-z.

13. Brotherhood JR. Heat stress and strain in exercise and sport. J Sci Med Sport. 2008;11(1):6-19, https://doi.org/10.1016/ j.jsams.2007.08.017.

14. Peters H. Evaluating the heat stress indices recommended by ISO. Int J Ind Ergon. 1991;7:1-9, https://doi. org/10.1016/0169-8141(91)90053-O.

15. Kampmann B, Piekarski C. The evaluation of workplaces subjected to heat stress: Can ISO 7933 (1989) adequately describe heat strain in industrial workplaces? Appl Ergon.2000;31(1):59-71, https://doi.org/10.1016/S0003-6870(99) 00024-1.

16. Kähkönen E. Comparison and error analysis of instrumentation and methods for assessment of neutral and hot environment on the basis of ISO standard. Kuopio, Finland: Kuopio University Publications; 1993.

17. Mairiaux P, Malchaire J. Comparison and validation of heat stress indices in experimental studies. Ergonomics. 1995;38:58-72, https://doi.org/10.1080/00140139508925085.

18. Mehnert P, Malchaire J, Kampmann B, Piette A, Griefahn B, Gebhardt H. Prediction of the average skin temperature in warm and hot environments. Eur J Appl Physiol. 2000;82 (1-2):52-60, https://doi.org/10.1007/s004210050651.

19. Malchaire JB. Occupational heat stress assessment by the Predicted Heat Strain model. Ind Health. 2006;44:380-7, https://doi.org/10.2486/indhealth.44.380.

20. Malchaire J, Piette A, Kampmann B, Mehnert P, Gebhardt $\mathrm{H}$, Havenith $\mathrm{G}$, et al. Development and validation of the predicted heat strain model. Ann Occup Hyg. 2001;45:123-35, https://doi.org/10.1093/annhyg/45.2.123. 
21. Wang F, Kuklane K, Gao C, Holmér I. Can the PHS model (ISO7933) predict reasonable thermophysiological responses while wearing protective clothing in hot environments? Physiol Meas. 2011;32(2):239-49, https://doi. org/10.1088/0967-3334/32/2/007.

22. Wang F, Gao C, Kuklane K, Holmér I. Effects of various protective clothing and thermal environments on heat strain of unacclimated men: The PHS (predicted heat strain) model revisited. Ind Health. 2013;51(3):266-74, https://doi. org/10.2486/indhealth.2012-0073.

23. Moran DS, Epstein Y. Evaluation of the environmental stress index (ESI) for hot/dry and hot/wet climates. Ind Health. 2006;44:399-403, https://doi.org/10.2486/indhealth.44.399.

24. Sohar E, Birenfeld C, Shoenfeld Y, Shapiro Y. Description and forecast of summer climate in physiologically significant terms. Int J Biometeorol. 1978;22(2):75-81, https://doi. org/10.1007/BF01552886.

25. Moran DS, Shitzer A, Pandolf KB. A physiological strain index to evaluate heat stress. Am J Physiol. 1998;275:R129-34.

26. Houghton FC, Yaglou CP. Determining equal comfort lines. J Am Soc Heat Vent Eng. 1923;29:165-76.

27. Vernon HM, Warner CG. The influence of the humidity of the air on capacity for work at high temperatures. J Hyg. 1923;32(3): 431-63, https://doi.org/10.1017/S0022172400018167.

28. Madsen TL. Measurement of thermal comfort and discomfort: Indoor climate. Copenhagen: Building Research Institute; 1979.

29. International Organization for Standardization. ISO 7730:1983. Ergonomics of the thermal environment - Analytical determination and interpretation of thermal comfort using calculation of the PMV and PPD indices and local thermal comfort criteria. Geneva: The Organization; 1983.

30. Aughey RJ, Goodman CA, McKenna MJ. Greater chance of high core temperatures with modified pacing strategy during team sport in the heat. J Sci Med Sport. 2014;17(1):113-8, https://doi.org/10.1016/j.jsams.2013.02.013.

31. Mazerolle SM, Ganio MS, Casa DJ, Vingren J, Klau J. Is oral temperature an accurate measurement of deep body temperature? A systematic review. J Athl Train. 2011;46(5):566-73.

32. Fuller FH, Smith PE Jr. Evaluation of heat stress in a hot workshop by physiological measurements. Am Ind Hyg Assoc J. 1981;42(1):32-7, https://doi.org/10.1080/15298668191 419316.

33. Lu S, Zhu N. Experimental research on physiological index at the heat tolerance limits in China. Build Environ. 2007;42:4016-21, https://doi.org/10.1016/j.build env.2006.06.029.

34. International Organization for Standardization. ISO 7726:2003. Ergonomics of the thermal environment - Instruments for measuring physical quantities. Geneva: The Organization; 2003.

35. Wenzel HG. Pulse rate and thermal balance of man during and after work in heat as criteria of heat stress. Bull World Health Organ. 1968;38(4):657-64.

36. Bernard TE. Occupational heat stress in USA: Whither we go? Ind Health. 2014;52(1):1-4, https://doi.org/10.2486/indhealth.100.

37. Epstein Y, Moran DS. Thermal comfort and the heat stress indices. Ind Health. 2006;44:388-98, https://doi.org/10.2486/ indhealth.44.388.

38. International Organization for Standardization. ISO 8996:2004. Ergonomics of the thermal environment - Determination of metabolic rate. Geneva: The Organization; 2004.

39. Bernard TE, Iheanacho I, Heat index and adjusted temperature as surrogates for wet bulb globe temperature to screen for occupational heat stress. J Occup Environ Hyg. 2015;12(5):323-33, https://doi.org/10.1080/15459624.2014. 989365.

40. Holmér I, Parson K, Alfano G, Griefahn B. Development and validation of the predicted heat strain model. Ann Occup Hyg. 2001;45(2):123-35, https://doi.org/10.1016/S00034878(00)00030-2.

41. Rowlinson S, Jia YA. Application of the predicted heat strain model in development of localized, threshold-based 
heat stress management guidelines for the construction industry. Ann Occup Hyg. 2014;58(3):326-39, https://doi. org/10.1093/annhyg/met070.

42. Wallace RF, Kriebel D, Punnett L, Wegman DH, Wenger CB, Gardner JW, et al. The effects of continuous hot weather training on risk of exertional heat illness. Med Sci Sports Exerc. 2005;37(1):84-90, https://doi.org/10.1249/ 01.MSS.0000150018.90213.AA.

43. Gagge AP, Nishi Y. Physical indices of the thermal environment. ASHRAE J. 1976;18:47-51.
44. Nag A, Nag PK. Heat stress of women doing manipulative work. Am Ind Hyg Assoc J. 1992;53:751-6, https://doi. org/10.1080/15298669291360490.

45. Bailes BK, Reeve K. Prevention of heat-related illness. J Nurse Pract. 2007;3:161-8, https://doi.org/10.1016/j.nurpra.2006.12.001.

46. Iampietro PF. Use of skin temperature to predict tolerance to thermal environments. Aerosp Med. 1971;42(4):396-9.

47. Pandolf KB, Goldman RF. Convergence of skin and rectal temperatures as a criterion for heat tolerance. Aviat Space Environ Med. 1978;49(9):1095-101.

This work is available in Open Access model and licensed under a Creative Commons Attribution-NonCommercial 3.0 Poland License - http://creativecommons.org/ licenses/by-nc/3.0/pl/deed.en. 